\title{
Globalisation, economic geography and the strategy of multinational enterprises
}

Peter J Buckley and

Pervez N Ghauri
Journal of International Business Studies (2004) 35, 255.

doi: | 0. I 057/palgrave.jibs.8400088

Correction to: Journal of International Business Studies (2004) 35, 81-98. doi: 10.1057/palgrave.jibs. 8400076

Due to a typesetting error, the name of one of the cited authors in the above paper has been incorrectly spelt.

Please note that the author cited as Teegan, both in the text and in the reference section, should have been cited as Teegen. Apologies are extended to Professor Teegen for this oversight. 